\title{
Satire and Domesticity in Late Eighteenth-Century Women's Poetry: Minding the Gap
}

\author{
Adeline Johns-Putra
}

This paper deals with the gap between the domestic and the poetic, which arises when the former is construed as trivial and quotidian and the latter imagined as the domain of the sublime, serious, and singular — the defamiliarised, even. Specifically, it explores the challenge faced by women writers in poeticising the domestic, particularly as the domestic sphere became — towards the end of the eighteenth century—the site and topic of ideological debate. It is a critical commonplace that the end of the eighteenth century saw the cultivation of a set of ideals promoting domesticity for women. Even given recent debate about how far these ideals can be said to have exercised an ideological or hegemonic function, it is at least widely acknowledged that an alignment of femininity and domesticity occurred in an imagined 'private sphere' of the home. Indeed, Michael McKeon's expansive study of both the historical phenomenon and critical discussion has emphasized that the 'domestic ideology of separate spheres' occurs, towards the end of the eighteenth century, as a way of articulating as separate what had already been distinct. As McKeon puts it, it 'spatializes an incremental and long-term sexual division of labor-a separation out of men's and women's work—as the mutual exclusion of 'outside' and 'inside' labor in terms of a dichotomy between waged and unwaged labor. The distinction, if not the separation, was traditional'. ${ }^{1}$ It is a commonplace too that such a set of ideas was, in the hands of women, a means towards authority and responsibility, and not a simple blunt instrument of male oppression; indeed it could sometimes take on 
the power of an ideology. Nancy Armstrong traces the rise of the domestic woman in terms of the 'development of a specific female ideal in eighteenth and nineteenth century conduct books and educational treatises for women, as well as in domestic fiction, all of which often were written by women', while Eve Tavor Bannet has suggested how a range of women writers, from Mary Wollstonecraft to Hannah More, 'promoted an as yet ideal and idealised division of labour between women and men—later to be dubbed "separates spheres"-which would allow wives to take over the important and culturally valued domestic offices from their husbands and take charge of the governance of children, servants, and dependents in the household themselves'. ${ }^{2}$ The doctrine of separate spheres, the rise of domestic womanhood-this socio-economic phenomenon is, in the work of many women writers in the late eighteenth century, either assumed (in metatextual terms) or promulgated (in textual terms). It is expressed as an aggregate of moral virtue, good sense, and reliability that was apparently inherently female, required for domestic bliss and hence an important factor in social stability.

Not surprisingly, then, in the process of rediscovering and repositioning late eighteenth-century women poets, critical attention has been paid to the way in which so much of their work foregrounds, even celebrates, the homely, the private and, as such, the resolutely un-poetic. Stuart Curran, whose work is seminal in the recanonisation of eighteenth-century women's poetry, has identified its defining characteristic as its 'quotidian' quality. This 'quotidianness', according to Curran, offered an antidote to the increasing emphasis on the sublime and transcendent in what we now characterise as (male) Romantic poetry. ${ }^{3}$ Curran's view has become representative: at a point at which 
the efforts of such recanonisation took substantial hold in the 1990s, Harriet Kramer Linkin captured the landscape of Romantic-age women's poetry thus:

As we restore the productions of women poets to offer a more comprehensive vision of the Romantic age, we have concentrated on a certain kind of women's poetry, a poetry of sensibility that emanates from or celebrates what is variously identified as communal (Susan Levin), the community (Wolfson), the quotidian (Curran), the affectional (Ross), the domestic (McGann), the sentimental (Julie Ellison), the feminine (Mellor), or the affective (Isobel Armstrong). ${ }^{4}$

Similarly, I have previously asserted that 'domestic ideology appears in some Romantic women's poetry [...] as a way toward an assumption of authority'. ${ }^{5}$

In this paper, however, I wish to explore another side to this question, and that is the ways in which Romantic-age female writers used poetry to interrogate rather than subscribe to the tenets of domesticity. In doing so, they exploited the conjunction of the poetic and the domestic. There is, potentially, a troublesome gap between the two, but also, therefore, a productive one. It is akin to the gap of burlesque, the difference between high and low, between the serious and the trivial. There are thus a range of positions and voices to be inhabited by those who seek to poeticise the domestic, and that range includes burlesque and satire. While some women poets used satire in the service of domestic womanhood, others exploited the gap between the high and low to complicate and critique the terms of domesticity. ${ }^{6}$ Indeed, I wish to speculate that it was no doubt tempting, for some women poets, to satirise it.

I deal here with a sample of work by four women poets of the 1780s and 1790s, in which the satirical and burlesque possibilities of the domestic emerge in different ways. 
For Anna Seward (1742-1809), the gap of burlesque is only just made discernible in her poem, 'Receipt for a Sweet Jar' (1810), whereupon it is ultimately discountenanced, and its satirical, even comic, effects are neutralised. Meanwhile, Anna Letitia Barbauld (1743-1825) presents a mock-heroic treatment of the domestic, 'Washing-Day' (1797), which both celebrates (to recall Linkin's words) and satirises it; indeed, the poem's playful ambivalence has resulted in a corresponding lack of resolution and agreement amongst the poem's recent critics on the intentions behind its mock heroic stance. Both these poets, in their depictions of the domestic, grapple with the slipperiness of burlesque and its tendency simultaneously to mock and heroicise, to trivialise and to elevate.

In contrast, in the work of two of Barbauld's and Seward's contemporaries, Elizabeth Moody (1737-1814) and Elizabeth Hands (fl. 1789), satire allows the domestic woman to become a sure target of ridicule and mockery. In a selection of poems from Moody's Poetic Trifles of 1798 and poems by Hands that appeared alongside her long poem, The Death of Amnon, in 1789, we are forced to acknowledge one of the more insidious aspects of the domestic woman - the way in which her authority is defined not against male influence in the public sphere but over other women. The authority enjoyed by the domestic woman derives, after all, from her power over working-class women; we are reminded of this when we note that Hannah More restricted her conduct-book advice to 'women of the superior class'. ${ }^{7}$ Thus, the possible gap between the domestic and poetic may also be expressed as the paradox of combining the roles of domestic woman and woman writer-the more directly concerned a woman is with domestic duties, the less time she has to pursue her work as a writer. While Barbauld's mock heroics and Seward's effusions belie a middle-class anxiety over what it means to celebrate 
domesticity in poetry, Moody and Hands expose such poetic treatments, and domestic womanhood overall, as an elision and effacement of the labouring-classes' contribution to the middle-class cult of domesticity.

Yet, it is worth noting that these women were not the first to utilise satire to comment on the ideological power of domesticity —critiquing, advocating, mocking, questioning it—for the brand of poetics explored here recalls the subtlety of an earlier generation of female poets, such as Mary Collier (1688?-1762) and Mary Leapor (17221746). Collier's The Woman's Labour has often been commented upon for its realistic portrayal of domestic labour from the perspective of the working-class woman. ${ }^{8}$ Leapor's sometimes comic pastorals, among them, 'Crumble-Hall', reveal the gulf between her life as 'a working-class woman, intimately acquainted with the perceptions and feelings of village, farm, and kitchen' and the 'high literary art she aspired to' ${ }^{9}$ Still, what is significant here is that, in the last decades of the eighteenth century, when the idealisation of domesticity began to look increasingly like ideology, and so much women’s writing sought to reify its vision of domestic womanhood, it was nonetheless a ground that continued to be contested rather than protected, much as it had been by the likes of Leapor and Collier.

Seward's 'Receipt for a Sweet Jar' initially presents itself as a typical example of women’s ‘quotidian’ poetry. The poem is a recipe for a potpourri of dried spices and flowers, written—one imagines—-to accompany the present of a sweet jar. Yet, a close reading of the poem and — more importantly_ of the revisions that were made before its final publication reveal a latent comic and mock heroic vein. This, it would seem, Seward 
worked hard to dismiss when she came to publish the poem, striving to close rather than expose the gap between 'mighty contests' and 'trivial things' and thus to elevate and celebrate the seemingly trivial. The poem appeared in Seward's Poetical Works of 1813, posthumously edited by Walter Scott. ${ }^{10}$ Yet, because Seward bequeathed to Scott a collection of carefully prepared manuscripts of a body of poetry spanning her career, it is likely that the poem's actual date of composition is much earlier. A manuscript of the poem, entitled 'An Accurate Receipt for a Sweet Jar in Inaccurate Heroics', sits in the Lichfield Record Office, amongst papers of Seward dating from the 1780s and 90s. ${ }^{11}$

Seward signals a mock-heroic stance from the outset, for the poem is written in heroic couplets, and sprinkled liberally with Seward's characteristic classical allusions and ornate diction. She invokes a muse, too, to sing the 'artful process' of putting together a summery sweet jar in anticipation of the winter months:

Through freezing hours would you pervade your rooms

With each fine odour of the summer-blooms,

Learn from the Muse to form the fragrant spell, And bid her rhymes its artful process tell. (1-4)

Yet, Seward's muse is a resolutely quotidian one, for her role is to provide a household recipe. In accordance with the language of recipes, the poem is insistently imperative to its reader, instructing her to 'Strew, with unsparing hand, that lovely flower' (6), 'Crop the rich spoils beneath the noon-day sun' (11) and ‘with sparing hand, / Bid luscious musk his potent scent expand, / A few small grains' (29-31). But, more than this, the recipient of the poem is not just consulting an anonymous recipe, she is, presumably, receiving a gift from a friend. As the poem progresses, formality is further dissolved into 
intimacy, for references to 'you' and 'your' give way almost without warning to 'thy' towards the end of the poem. As the poem directs its reader to remember to add a liberal amount of salt to the layers of ingredients in the jar, the tone shifts midway through this instruction:

Still, as you spread them, every layer between,

Profusely let this white preserver gleam,

While scantier sprinklings of the spicy dust,

By art thus blended, aid the poignant gust.

And let each rising morn behold with care

Thy busy fingers mix each former layer (43-48; emphasis added)

In short, while the poem's ornate language and classical references, combined with the description of producing the sweet jar as 'art', constantly threaten to tip the recipe into the self-consciousness of highly wrought ekphrasis, we are ultimately reminded that the finished product_-'thy treasured flowers' and 'thy vase' — is a private memento.

The catalogue of ingredients that comprises the main body of the poem continues the theme of friendship and domesticity. The poem moves from homely English flowers_-violets, roses, lilacs ('syringas')—-to exotic spices:

With cinnamon let cloves and mace descend

And in the marble vase their virtues blend,

One ounce of each

The domesticity of the sweet jar, then, embraces a world of ingredients. The overall effect is one of exoticism captured and contained, of tropical heat transferred to an English drawing room: 
odours, rich as those of Saba's vale,

Rise on hybernal Albion's bleakest gale,

Sweets, which the breath of her gay months excels,

While in thy vase eternal summer dwells. (53-56)

The friendship motif is carried further by a metaphor that aligns the jar's essential preservative—-salt—with friendly protectiveness:

Yet liberal most the snowy mineral spread

Between each layer, in sparkling plenty shed,

Since where bright Salt her crystalines extends,

She brings an active host of powerful friends,

To whose pervading and protecting sway,

Fell Dissolution yields his languid prey. (34-40)

A significantly feminised salt exerts influence over her-in turn—'powerful friends', (presumably the chemical components to which salt eventually breaks down). All have a preservative effect. It is salt, signifying lasting, caring friendship, that is the essential ingredient. The recipe for the sweet jar has become a trope for friendship, to be juxtaposed and indeed set above the formal heroic content that it has presumably displaced.

Yet, as much as we may hope to read Seward’s mock heroics as a celebration of the domestic, the slippage between trivialising and heroicising the domestic is always a risk in Seward's poem. The trappings of heroic poetry, such as personification and allusion, are in danger of being indulged to such an extent that they occlude rather than 
enhance the intimacy and domesticity that mark the sweet jar recipe. Such is the case in lines such as these:

When Fraxanella’s spicy sighs exhale,

And pale Syringas languish on the gale;

When all the aromatic tribe entwine

Their vernal garlands round Hygeia’s shrine,

Crop the rich spoils beneath the noon-day sun,

And be with these thy grateful task begun! (7-12)

One could argue that the faint ridiculousness that accompanies this bombast is surely a deliberate mockery of - rather than a simple investment in — the heroic mode as a means of describing the domestic. However, it is not just the sense of overblown heroics but the juxtaposition of such heroics with the mundanity of a sweet jar that contrive towards a comic effect. And if there is fun being had here at the expense of overly serious poetry, it is not easy to tell whether there is a deliberate gibe at the imagined poet who would write such lines or an unfortunate joke on the poet who has indeed written them. If her intention was a celebration of the domestic, Seward must also have been well aware that heroicising could so easily look like mocking.

A comparison of the manuscript of the poem with the published version is revealing. First, Seward's original title for the poem, 'An Accurate Receipt for a Sweet Jar in Inaccurate Heroics', juxtaposes heroic mode with domestic subject matter and suggests the relative importance of the latter (for it is the recipe that is rendered accurately, not the heroic couplets). Yet this juxtaposition delineates the contrast between domestic and poetic, and raises the stakes in exploiting it. A look at the poem in 
manuscript suggests that, in revision, Seward foregrounded the themes of domesticity and friendship. The use of the intimate address of 'thee' and 'thou' were introduced to the final version, emphasising the informal tone of the poem, and suggesting that the abrupt switch in formality is indeed a deliberate one. Moreover, the exotic origins of her ingredients are only made implicit, as the manuscript's mentions of 'Hispania's Lemons' (24) and 'Indian spices' (31) are removed, thus allowing the foreign to be more easily compressed and confined within the domestic in the finished poem.

In addition, Seward downplayed the poem's loftiness and ornateness, perhaps because she realised that the more elevated the form, the larger the gap of burlesque, and hence the more difficult it would be to control, as it were, the direction of mockery. Thus, in the central salt metaphor of the final version, the high-flown imagery characteristic of other parts of the poem is absent, and the comic possibilities of the gap are therefore avoided. The same cannot be said, however, about the manuscript version of the poem:

And most essential is that mineral's claim, Which once was flying Lot's too curious Dame.

As white the sparkling crystalines extend Whate'er embraces them shall find a Friend, An host of Friends, to whose protecting sway Fell Disposition yields its destin’d Prey. (40-45; original emphasis) The result of the clash between the literary (or, in this case, the scriptural) and domestic is simple absurdity. The introduction in a recipe of so serious an allusion as the biblical flight from Sodom stretches the gap beyond the capacity of the poem. One could say that this comic effect is captured in miniature in the bizarre juxtaposition of Old Testament 
and colloquialism in the epithet, 'Lot's too curious Dame'. The trope of friendship is insufficiently developed here; indeed, the metaphor is buried in the allusion of these lines. Hence, any rationale for a celebration of domesticity is absent. That Seward specifically removed the scriptural reference in the final poem suggests, I would argue, an unease about the obvious quotidianness of her subject. This unease was so strongly felt here because what, after all, is more prosaic than household salt? Yet, such unease pervades the final piece. The gap between the heroic and the domestic is certainly an uncomfortable one, and we can only speculate on the extent to which Seward intended that discomfiture should be the final effect of this particular poeticising of the domestic.

Barbauld's ‘Washing-Day’ was originally published in the Monthly Magazine in 1797; the periodical had been founded the previous year, with Barbauld's brother, John Aikin, as its literary editor. ${ }^{12}$ As Elizabeth Kraft notes, it is difficult, given this information, to ascertain the poem's date of composition: ‘To help her brother in this enterprise, Barbauld could have allowed him to print a favourite poem over ten years old, or she could have composed a new poem ${ }^{13}$ It is possible only to know that the poem was written after 1783, the year the Montgolfier balloon—which supplies the poem's final metaphor—was launched.

The poem, now one of Barbauld's most reprinted, is a blank-verse description of a typical laundry day, which, as Kraft so carefully describes it, was, for the eighteenthcentury household, 'a day of great physical hardship [...] The work was difficult, demanding the strength to lift heavy vats of water, the stamina to beat the clothes, or to stir them in sudsy water, the patience to mangle the rinsed linens and to smooth the wash 
with stones or irons heated over a fire or in boiling water' ${ }^{14}$ In telling the details of washing day in poetry, Barbauld signals her poem’s mock-heroic credentials, as does Seward, at the very start. Barbauld domesticates the conventionally epic muses with:

The Muses are turned gossips; they have lost

The buskin'd step, and clear high-sounding phrase, Language of gods

These muses are further reduced in number to, and identified as, a single 'domestic Muse / In slip-shod measure loosely prattling on' (3-4), who is invoked to 'sing the dreaded Washing-Day' (8; original emphasis). For Barbauld, the trials suffered by the housewife on washing day are comparable with those endured by more obvious heroes, such as martyred saints and tortured princes:

Saints have been calm while stretched upon the rack, And Guatimozin smil'd on burning coals;

But never yet did housewife notable

Greet with a smile a rainy washing-day. (29-32)

It is not difficult to read the poem as a heroicisation of the domestic, and of a celebration of female-related interests over male ones. Barbauld constructs the day as an instance of women's business taking precedence over men's: the home is entirely given over to the business of washing, a business overseen by the woman of the house, and, significantly, it is the husband who is most inconvenienced by the day's activities. Though he 'call'st thyself perchance the master there' (34), he is sorely mistaken, for he is displaced, his garden walks physically obstructed by lines of washing veritably flapping in his face and his demands for food met with short shrift. More than that, however, Barbauld presents 
washing day as a trope for the absence of patriarchal hierarchy in the domestic space, since that space is the domain of the domestic woman. Thus, domestic details are made to inhabit a heroic mode in her poem, and female voices are literally heard over male ones: the so-called master of the house is instructed to 'ask not, indiscreet, / Thy stockings mended' (36-37), and his visitor 'In silence dines, and early slinks away’ (57), and, in Barbauld's own childhood reminiscences of washing day, 'my mother's voice was heard, / Urging dispatch’ (74-75). In other words, Barbauld's poem rewrites masculine heroic poetry while depicting the way in which an emphatically female activity has the power to displace men, and there has been no shortage of recent commentators to say so. As Haley Bordo suggests of the poem, 'it performatively interrupts the loaded lines of men's verse while constatively describing the interruptive "petty miseries" of the "dreaded" washingday'. ${ }^{15}$ Ann Messenger is even more enthusiastic of the proto-feminist potential of Barbauld's apparent heroicisation of domesticity: 'washing day loomed large on the domestic front as the siege of Troy or Heaven on the international or cosmic. It was when nothing else could be done, when the women of the family and their helpers reigned supreme and the husbands and fathers lurked in the shrubbery or went to the office, unwanted and unattended to'. ${ }^{16}$

Nonetheless, as we have already seen, burlesque is capable of working in more than one direction. Barbauld's mock heroic mode always possesses the potential to mock—not heroicise — the domestic. Thus, Messenger couches her optimistic reading of the poem with this warning about Barbauld's domestic subject matter: 'Its importance gives a doubleness to the mock heroic treatment it gets in her poem. Clearly, the events of such a day are not true epic matter: no pagan or Christian heroes wage war with Troy or 
Satan'. ${ }^{17}$ Messenger notes further that 'the largeness of the language is both appropriate to the largeness of the events, from the woman's domestic point of view, and comically, mock heroically, inappropriate, because the domestic is considered necessarily trivial’ ${ }^{18}$ Kraft is even more circumspect, suggesting simply that "“Washing-Day” cannot be read as a didactic attempt to garner sympathy or appreciation for women's work' ${ }^{19}$ Kraft warns especially that Barbauld is capable of playing the mock heroic both ways: 'the mock heroic conventions by which Barbauld introduces the events of washing-day allow her both to assert the way the day trivialises other activities and to suggest that the activities of the day are themselves relatively trivial' ${ }^{20}$

The sticking point in critical commentaries of the poem, and in analyzing the tone of Barbauld's treatment of the domestic, is its final, puzzling imagery. Here, the soap bubbles blown by the poet as a girl are compared to the first hot air balloon launched by the Montgolfier brothers:

Sometimes thro' hollow bole

Of pipe amused we blew, and sent aloft

The floating bubbles, little dreaming then

To see, Mongolfier, thy silken ball

Ride buoyant thro' the clouds—so near approach

The sports of children and the toils of men.

Earth, air, and sky, and ocean, hath its bubbles,

And verse is one of them-this most of all. (79-86)

In view of the poem's juxtapositions of heroic with domestic, this seems simply one more such alignment—-the pioneering achievements of men are as trivial as child's play and as 
insignificant as the soap bubbles of washing-day. Yet, where the significance lies is debatable. Barbauld does invoke a sense of awe about the Montgolfier balloon and does seem to belittle her soap bubbles; by the time she comes in her final line to belittle her verse depiction of washing day, it seems she is belittling the fuss and bother of washing day too. Messenger posits that this is Barbauld's half-hearted attempt at blunting her satire on men: 'This final ending masks the announcement of the satiric point, which loses what would have been the place of most emphasis, the last line. The sting is further lessened by the claim that the poem is a mere bubble'. ${ }^{21}$ Nonetheless, for Messenger, Barbauld could be delivering a gibe not at her poetry but at all poetry: 'Mrs. Barbauld is not simply wallowing in self-deprecation in her final lines. For she has said "And verse is” a bubble, not just her own verse'.22 Bordo would seem to agree, and to suggest that this amounts to another critique of masculine achievement, for it is men's verse that suffers attack here, just as it is a male verse tradition that is undermined by Barbauld's mock heroics: 'The question that many of us will ask when we read these final lines is: to what does “this” refer? Does it refer to Barbauld's “verse” itself? If so, is she being selfdeprecating, as a proper lady ought to be? [...] Perhaps. But, as likely is the possibility that, since 'Washing-Day' is made up of men's verse, "this” refers to their "verse”" (original emphasis). ${ }^{23}$ According to Bordo, the hot-air balloon is, for Barbauld, a 'Miltonically sublime object' and, therefore, 'the final lines of her poem continue to expose the genre of sublime poetry as sheer artificial performance'. ${ }^{24}$ It is possible, but not certain, that Barbauld's final words serve metaphorically to deflate the pretentiousness of the masculine business of high poetry. 
Nonetheless, the critical uncertainty that surrounds these lines should alert us to their inherent ambivalence. For Kraft, these final lines are a fitting conclusion to a poem that is doubled-edged throughout. The poem invokes the categories of 'masculine and feminine' or 'domesticity or creativity', but 'actually fuses what [other critics] regard as irreconcilable qualities, and it does so in the very image they misread: the image of the Montgolfier balloon'. ${ }^{25}$ According to Kraft, Barbauld's final image is a celebration of the imagination, and the way it 'can both flourish in and transcend the domestic context'; in other words, Barbauld is indeed simultaneously trivializing and heroicising the domestic drudgery of washing day. ${ }^{26}$ Yet, Barbauld's deliberate use of the mock heroic mode, and therefore her awareness of the gap between the domestic and the heroic, cannot be dismissed. In invoking the muses, in alluding to past heroes, in manipulating the gap of burlesque, Barbauld attracts our attention to this gap, promises a burlesque treatment of it, and thereafter abandons it. I would suggest that, afflicted with the same kind of unease about the heroic possibilities of the domestic that we see in Seward's poem, Barbauld offers a non-committal, even bathetic conclusion. The transcendence that Kraft identifies is not a transcendence of the domestic context, but a wilful transcendence of —and therefore a refusal to confront-the difficulties of treating this domestic context in poetry.

The difficulties in countenancing this gap arise, ultimately, from a very deep difficulty in reconciling the two in real terms — what neither Seward nor Barbauld allows us to acknowledge is that the domestic and the literary are two very different sorts of labour, marked by different socio-economic aims, conditions, and rewards. So distinct are they that the gap between them is more easily exploited than denied. Indeed, this gap 
offers itself up for comic effect, and that comic effect is capable of carrying a biting social critique.

This is what Elizabeth Moody demonstrates. Little is known about Moody, but she is identifiable as a contemporary of both Seward and Barbauld. Born Elizabeth Greenly to an affluent family in Kingston-upon-Thames in 1737, she was fluent in French and Italian, and married a Dissenting clergyman at the age of forty. ${ }^{27}$ As Mary Waters describes it, 'the Moody marriage appears to have been a truly companionate one, both parties sharing lively wit and a love of literature and criticism, but Christopher Moody's income and social standing were beneath what Elizabeth had been accustomed to, and the couple were often strapped for cash' ${ }^{28}$ From about 1789, Moody was a regular and apparently valued reviewer at the Monthly Review. ${ }^{29}$ Her only volume of poetry, Poetic Trifles, appeared in 1798 (since then, Moody’s poetry and prose have been critically edited by Jan Wellington in her unpublished doctoral dissertation of 1997, and a selection appears also in Roger Lonsdale’s anthology of Eighteenth-Century Women Poets). ${ }^{30}$

Amongst the many poems in Moody's volume are two companion pieces, 'A Prophecy by Miss R. P_' and 'Sappho, Tempted by the Prophecy, Burns Her Books and Cultivates the Culinary Arts'. These offer a satirical comment on literary women who affect a pose of domesticity in order to enhance their marriageability. The first poem contains the advice of a typically domestic woman, presumably suggesting that 'Sappho' abandon literary work for the 'useful sense' (6) of domesticity. The first and last lines of this brief poem capture nicely the kernel of its message:

When Sappho throws her verses by, Can beat the cake, and bake the pie; 


\section{$[\ldots]$}

Then—and not till then—she'll find,

Fortune, Love, and Hymen kind. (1-2; 13-14)

We then trace Sappho's response in the second, more substantial poem. Obviously, the heroine is not the legendary female poet but a name assumed by the speaker of the poem, identifiable as a woman with a love for literature and languages, and therefore possibly with Moody herself. Indeed, this poem shifts midway from the first person, who articulates the poet's rejection of her favourite Italian poetry in a half-hearted attempt to learn the 'more winning arts' (19) of cookery, to the fanciful third-person of 'Sappho', who is imagined to have successfully carried out her rejection of poetry for domesticity: 'When all extinct are Sappho's rhimes; / When none but Cooks applaud her name' (3839). The poem's mock-heroic tone, as with Barbauld's and Seward's poems, is initiated by an invocation of a domestic muse. The poet sets aside a canon of male writersGuarini, Dante, Petrarch, Tasso, Ariosto — to beseech the 'Goddess of Culinary Art' (17) to:

take possession of my heart!

Teach me more winning arts to try,

To salt the ham, to mix the pie' (17-19)

Once this invocation has been established, the clash of domestic with poetic begins in earnest. The poem launches into a self-consciously poetic description of cooking. Allusive, metaphorical language recalls Seward's mock-heroic sweet jar recipe but here exploits in earnest the ridiculousness of the gap between the poetic and domestic:

Then teach thy votary how to make 
That fair rotundo-a plumb cake;

To shake the compound sweets together,

To bake it light as any feather,

That, when complete, its form may show

A rising hillock topp'd with snow;

$[\ldots]$

To strain my jelly fair and clear,

That there no misty fog appear;

But plain to view each form may rise

That in its glassy bosom lies. (25-30; 33-36; original emphasis)

The very next lines, in switching from the first person to the third, signal a switch too from high burlesque to low. As if to demonstrate how easy it is to burlesque the domestic in poetry, Moody’s allows the mock-heroic technique of couching domestic subject matter in poetic language to give way to a Hudibrastic satire, placing literary figures in compromising situations with food and cooking utensils. When 'Sappho' has well and truly turned her back on poetry, we find that:

Pope shall sing beneath minc'd-pies;

And Eloise in her tin shall mourn,

Disastrous fate and love forlorn;

Achilles too, that godlike man,

Shall bluster in the patty-pan;

And many a once-lov'd Grecian chief,

Shall guard from flames the roasting beef. (42-48; original emphasis) 
Importantly, Moody's burlesque is accompanied by sharp satire. Her first target is nominally herself, or at least the woman who would so foolishly give up not only the joys of reading her 'lov'd Italian themes' (10) by the fire but the 'name' (39) and 'fame' (40) that come of writing poetry. But the sting of the satire is reserved for the 'Goddess of Culinary Arts' herself, who—-because feminised—becomes emblematic of women's wilful interpellation into the cult of domesticity. For it is Miss R. P. who has instructed her friend to find love through domestic womanhood, and Sappho who blindly responds by burning her books. The Goddess, then, is 'Sorceress' (53) and witch, kinswoman to the ‘sisters of the heath, / Whose mystic sound betray'd Macbeth’ (55-56). Her arts prove to be 'Fallacious charms' (57) that serve only to cheat 'Sappho' 'with ambiguous sense' (58), and to offer the 'Severest torments' (59) of 'disappointed love' (60). Moody thus not only identifies domestic womanhood as a front, a role assumed by women in order to live up to male expectations of female behaviour, but as a significantly less rewarding endeavour than literature.

By pointing out that domesticity is simply a pretense at domestic diligence in order to secure male approval, Moody suggests that the art implied by the 'culinary arts' is really artfulness. Domesticity, in Moody's poem, is a synonym for the sub-intellectual, polite accomplishments that women value not in or for themselves but in order to obtain husbands; it is apparently utterly alien to the inherently rewarding and challenging process of reading and writing literature. In contrast, when Seward describes the 'artful process' (4) of putting together a sweet jar, she seems to have in mind a domesticated ekphrasis, which produces an expression of homely skill not antithetical to, but down the scale from, high art. Thus, her poem proclaims (if problematically) the inherent value of 
domestic activity. In addition, when Barbauld compares verse with the bubbles of washing day, she is at least reminding us that she has attempted to equate domestic subject matter with more traditionally poetic heroics, even if she holds back from commenting decisively on which is more worthwhile.

Yet Barbauld and Seward are able to discuss domesticity on the same terms as the more leisurely business of poetry because they have elided the labour that lies at the heart of the domestic sphere. What Seward's preparation of the sweet jar has in common with 'art' is that they both require free time. And Barbauld's troublesome bubble metaphor, which unites 'the sports of children' with 'the toils of men' (84) and then equates both with the versifying of poets, has the effect of distracting from, and thus effacing, the sheer hard work of washing-day. After all, it relocates the poet's voice with Barbauld as a pampered little girl, the servants' 'petted one' (64), who will grow to become just like her mother, 'Urging dispatch’ (75) of those same servants and casual washer-women. With 'All hands employed to wash, to rinse, to wring, / To fold, and starch, and clap and iron, and plait' (76-77), Barbauld as a girl is free to 'sit me down, and ponder much / Why washings were' (78-79). The writing of a poem, the putting together of a potpourri, the management of manual labourers, are all hardly onerous as physical tasks, though both poets attempt to inject a sense of activity into them, from Seward's 'busy fingers' (48) to Barbauld’s descriptions of how 'briskly the work went on' (75). What neither Barbauld nor Seward reveals is that domestic womanhood, as the province of ladies of the middle class, involves alternately urging or ignoring the work of others rather than doing that work. As Donna Landry remarks, 'Barbauld writes as if addressing such a domestic topic were newly fashionable, as if the province of such verse belonged to privileged women 
writers like herself, “loosely prattling on”, in ever greater numbers, of domestic events and rural simplicity where Milton once tackled sublimer subjects, but doing so from a leisured perspective, surrounded by and made possible by silent female servants'. ${ }^{31}$ As Armstrong notes, 'it is a curious thing that even though conduct books represented aristocratic behaviour as the antithesis of the domestic woman, they never once exalted labour' ${ }^{32}$ This is because the domesticity advocated by conduct books is certainly not about labour. Combining domestic womanhood with literary composition meant striving to bridge a gap in aesthetic terms, but did not require resolving it in any material sense, for middle-class life surely afforded women the leisure time to write as the demands of providing labour would not have done for working-class women.

Moody's depiction of domestic womanhood as a calculated strategy hints at its hypocritical pretense at labour and therefore implies its deliberate effacement of an economic reality. In another poem in her Poetic Trifles, she offers further insight into the workings of domestic womanhood. The ‘Housewife’s Prayer, on the Morning Preceding a Fête' satirises the domestic woman as an over-zealous vanguard of her class. This poem too begins with a mock-heroic invocation, or, more accurately, an apostrophe, for the entire poem is a prayer spoken to 'Economy' personified, that virtue extolled by the likes of Hannah More as the means by which the income earned by a man in the public sphere could be regulated and transformed into stability and ease in the domestic sphere. Yet, here, Moody constructs it as parsimony taken to extreme ends:

Goddess ador'd! who gain'd my early love, And form'd my mind thy precepts to improve;

Taught me to practise each penurious rule, 
And made my heart a pupil of thy school;

Taught me that waste is an atrocious sin

And bade me cull from dust the scatter'd pin:

Rememb’ring this thy maxim to revere,

One pin a day collects a groat a year. (1-8; original emphasis)

Even given the effects of inflation, an annual saving of a groat, that is, fourpence, is hardly spectacular. More importantly, however, Moody shows how the housewife's economy is as much about preserving her wealth as safeguarding it from others, namely the servants, who will return from the fete a little more disposed than usual to make free with the contents of their mistress's larder:

This night impart thy parsimonious grace

To all that wasteful tribe, the vassal race;

Vouchsafe protection to each sacred hoard, And grant no lavish hand profane my board.

Infuse thy spirit in the chosen fair,

Ordain'd the tea and coffee to prepare;

May she distribute both with frugal hand!

And patient let the brewing tea-pot stand $\quad$ (25-32; original emphasis)

The contrast between the poem's religious language and its petty concerns of material savings creates a pointed comment on the housewife's less than Christian selfishness. The transaction at the heart of the doctrine of separate spheres is visibly about an exchange of a man's wealth and a woman's management of that wealth; what is exposed by this poem is the way in which that management is founded on the subordinate labour 
of other women. It is not stretching the truth to say, then, that the poem's satire is derived from our understanding that the wealth that the housewife so carefully guards is translated into status and comfort by those from whom she guards it.

To read the rest of Moody's 'domestic' poems in the context of these satirical swipes reveals, then, a spirit of satire even when it is not immediately obvious. A final poem on housewives, 'The Housewife; Or, The Muse Learning to Ride the Great Horse Heroic', is, at first glance, a paean to housewifely activity more in the mould of Seward's celebration of quotidianness than Moody's satirical gibes. It takes a closer reading to discover whether the gap between the heroes and housewives signalled by the title is the gap of burlesque. Indeed, that there is a difference between this poem and Moody's other comments on the domestic is indicated by the use of blank verse rather than couplets, suggesting a serious, non-ironic attempt at heroicising the housewife. However, the metaphor by which the poet refers to her employment of blank verse- that the muse is 'learning to ride the great horse heroic’-firstly, conveys a less than reverential visual image and, secondly, suggests that the poet is testing out her heroic metrical skills on the relatively undemanding terrain of domesticity. Similarly, although the housewife starts out as a superior kind of female—a 'useful maid [who] to deeds / Of more importance gives her day' (35-36) than the 'ye idle fair! ye time / Destroyers! who live to dress, and flaunt, / And flirt' (32-34)—she becomes increasingly a figure of mild ridicule as we proceed through the poem. At several points, an ostensibly heroicising gesture is not so easy to distinguish from one of mockery. For one thing, this housewife soon resembles the parsimonious housewife of the 'Housewife's Prayer', for she is 'vers'd / In tricks of vassal-kind' (42-43). Again, a bit of visual imagery is what establishes an air of 
absurdity, the housewife and her trusty bunch of keys described as being 'with / Her economic ensigns deck'd' (47-48), and therefore endowed with a mock earnestness that cannot compete with the paraphernalia of conventional heroes. For another, when the poet reminds us that homely matters are not so alien to heroic poetry by alluding both to Milton's Eve setting the table for Raphael and to the meat roasted by Homer's Agamemnon in a sacrificial gesture, one could argue that the gap is widened rather than closed. For while we compare this protagonist with the mother of humankind or the commander of the Achaians, we must consider too whether her domestic efforts really do resound with quite the same significance as theirs:

Say, Muse!

[...] thou hast not disdain'd to sing, in days

Of yore, of Culinary Arts.—Both when

The beauteous Mother of mankind regal'd

Her Angel guest, and from sweet kernels press'd

The dulcet creams—And when the Grecian chiefs

Reser'vd a portion of the victim slain,

And AgAmEMNon help'd to roast the Beef. (48; 50-56; original emphasis)

The poem proceeds through varying scenes of faint ridiculousness, from the mockOdyssean encounter with the 'feather'd / Monsters' (74-75) of the poultry-yard, to the housewife's consultation of 'known manuscripts of ancient fame' (96) that, far from yielding any immortal prophecy, present only recipes: 'she turns the time-worn page / To find that celebrated Pie' (101-02; original emphasis). 
It is when we reach the end of the poem that the problematic heart of Moody's satire reveals itself:

What more this busy active dame perform'd, In the next Canto shall the Muse rehearse.

The HouSEWIFE's toils an ample theme supply;

Returning toils that rise with ev'ry Sun.

O days of ALBION! happier far I ween,

When Woman's knowledge own'd its boundary here! (130-35; original emphasis)

The poet's heroicisation of housewives coincides with a conservative condemnation of female learning (and, presumably, female writing). A paradox therefore emerges - that a celebration of domestic woman's circumscription within the domestic sphere would be impossible without this particular writing woman's participation in that celebration and hence her wilful assumption of a position outside that sphere. As if paralysed by this paradox, the poet ends abruptly, ominously promising another canto but concluding at the very line — the wished-for 'boundary' to woman's knowledge—-that she knows she has presumed to overstep.

Moody's satirical exposure of the cult of domesticity—particularly of its class foundations and its circumscription of female intellectualism—is especially interesting when we consider that she was herself of the middle classes and had therefore some slightly greater freedom in pursuing her literary ambitions than her working-class counterparts. Offering a complementary approach are the poems of the working-class 
poet, Elizabeth Hands. Hands's only publication was a volume of poetry, entitled The Death of Amnon, in 1798. (The volume has since appeared as a modern facsimile reprint with an introduction by Caroline Franklin, and some of its poems, like those of Moody's, have been reproduced in Lonsdale's anthology of Eighteenth-Century Women Poets. ${ }^{33}$ ) Our knowledge of Hands, as Landry shows, consists entirely of what may be gleaned from the poems in this volume: 'Reconstructing Elizabeth Hands's life requires some guesswork since no autobiographical or biographical narratives accompany her poems' ${ }^{34}$ Hands was, it would seem, a domestic servant from Bourton in Warwickshire, who was married, had at least one daughter, and was assisted in publishing her work by the dramatist, Bertie Greatheed (1759-1826), to whom she dedicated the book.

Amongst the poems in this volume are two self-reflexive companion pieces; their importance is suggested by their position immediately after the long scriptural verse narrative that is the title piece of the publication. As Landry writes of Hands and these poems:

She satirizes more acutely than anyone else the peculiar situation of the workingclass writer in England on the eve of the French revolution. Not since Swift have we seen comical satirical verse in the order of Hands's 'A Poem, On the Supposition of an Advertisement Appearing in a Morning Paper, of the Publication of a Volume of Poems, by a Servant-Maid' and A Poem, on the Supposition of the Book having been published and read. ${ }^{35}$

In a skillful demonstration of literary ventriloquism, the two poems depict the drawingroom conversations of several denizens of provincial upper-class life on the occasions described in the titles. In the best tradition of eighteenth-century satire, the ladies of both 
poems are all caricatures of social types_-among them, Mrs Prudella, Miss Prim, Miss Flounce, Miss Noworthy. Significantly, one of these stereotypes is Miss Rhymer, the poetasting lady of leisure, whose very presence as a caricature problematises any easy construction of the difficulty with which late eighteenth-century women juggled the roles of the proper lady and the woman writer. By depicting, first, the unembarrassed snobbery of the leisured classes and then the vacuity of their lives, Hands manages a telling class critique. Thus, in 'A Poem, On the Supposition of an Advertisement Appearing in a Morning Paper, of the Publication of a Volume of Poems, by a Servant-Maid', Lady Marr-joy announces of the presumptuous maid-servant turned poet, 'Was she mine I'd employ her as long as 'twas light, / And send her to bed without candle at night' (23-24). And in 'A Poem, on the Supposition of the Book having been Published and Read', Mrs. Devoir purports to 'know something of her' (78), before asserting, 'I saw her, but never convers'd with her-though / One can't make acquaintance with servants, you know' (82-83, emphasis added). Yet, protestations that servants should not 'be reaching at things so much out of their sphere' ('A Poem, On the Supposition of an Advertisement', 33), although based on a belief in their class's innate superiority, belie the reverse. The much-vaunted stupidity of servants contrasts sharply not just with the emptiness of the ladies' existence but with the simple rewards of labouring-class life that are depicted in the pragmatic pastorals of the rest of the volume, poems such as 'Contentment', 'Lob’s Courtship’ and ‘On the Author’s Lying-In, August, 1785’. Pointedly so, Hands makes evident her intellectual and moral superiority to the class of her employers, with, for example, Miss Gaiety’s ignorance of the scriptural basis of the narrative of Hands's title poem, The Death of Amnon: 
A Scripture tale?—ay—I remember it—-true;

Pray, is it i' th' old Testament or the new?

If I thought I could readily find it, I’d borrow

My housekeeper's Bible, and read it to-morrow. ('A Poem, On ... the Book

Having Been Published', 45-48)

Because Hands, or at least the persona she inhabits in these poems, is a domestic servant, it is no surprise that the hypocrisy and the affectations of these ladies of leisure hinge on the domestic. Their reliance on domestic servants brings into focus the affectation of domestic ability so many of them assume. The domestic woman herself makes an appearance as Mrs. Domestic, who insists, unsurprisingly, that servant girls have no business writing poetry. Remarking of another versifying maidservant, she opines:

Had she wrote a receipt, to’ve instructed you how

To warm a cold breast of veal, like a ragou,

Or to make cowslip wine, that would pass for Champaign;

It might have been useful, again and again. ('A Poem, on the Supposition

of an Advertisement...', 49-52)

What is pertinent here is the consistency with which domestic womanhood is satirised by both Moody and Hands, suggesting a familiarity with this social type for both these poets and probably their readers; we note, for example, the frugality of Mrs. Domestic, in remarking on the usefulness of passing off cowslip wine for champagne. Also worth noting is the way in which Hands satirises the recipe as a middle-class simulation of domestic work, bringing to mind Seward's attempt at just this: 
Says Sir Timothy Turtle, my daughters ne’er look

In any thing else but a cookery book:

The properest study for women design'd;

Says Mrs. Domestic, I’m quite of your mind.

Your haricoes, ma'am, are the best I e'er eat,

Says the Knight, may I venture to beg a receipt.

'Tis much at your service, says madam, and bow'd,

Then flutter'd her fan, of the compliment proud. ('A Poem, On the Supposition of the Book having been Published...', 60-67)

A distinct lack of direct involvement in domestic duties is everywhere evident here.

Hands's ladies of leisure are happy to oversee the business of cooking without engaging in it: Sir Timothy’s daughters merely look into cookery books, while Mrs. Domestic’s culinary prowess is expressed by—what else?—a recipe. Meanwhile, any actual cooking is, of course, carried out by servants.

What the poem achieves, in other words, is a satire on the vacancy of upper-class leisure. Thus, Hands's comic gap lies not so much between the poetic and the domestic as it does between the sublime and the potentially ridiculous posturing of a middle-class phenomenon such as domestic womanhood. The ladies foolishly attempt to mock Hands's poems on the basis of the former while remaining stoutly ignorant of the latter:

A servant write verses! says Madam Du Bloom;

Pray what is the subject?—a Mop, or a Broom?

He, he, he,—says Miss Flounce; I suppose we shall see 
An Ode on a Dishclout—what else can it be? ('A Poem, on the Supposition of an

$$
\text { Advertisement...', 11-14) }
$$

Yet, it is the endless round of provincial gossip—-the 'news of the day' ('A Poem, On the Supposition of the Book having been Published...', 8) — that is shown to be inadequate to a performance in poetry:

What wife was suspected, what daughter elop'd, What thief was detected, that 'twas to be hop'd

The rascals would all be convicted and rop’d;

What chambermaid kiss'd when her lady was out;

Who won, and who lost, the last night at the rout;

What lord gone to France, and what tradesman unpaid, And who and who danc'd at the last masquerade;

What banker stopt payment with evil intention, And twenty more things much too tedious to mention.

Ultimately, then, Hands's joke is on the middle-class lady of leisure, and on the lady's pose of useful, busy, active domestic womanhood.

The work of these four women poets, occurring towards the end of the century, demonstrates that the contours of the cult of domesticity were continually being shaped, even though a long view of the era would suggest that this is precisely the moment when it was being hardened into a 'private' sphere to be juxtaposed with a 'public' one. The slippages enabled by burlesque, the complexities and ambiguities inherent in literary satire, the unpredictable turn of its mockery from ridicule to jest, play out, at the level of 
text, an uncertainty inherent at the level of ideology. Indeed, this uncertainty reminds us of the conditions of ideology itself_-ideas inform material practices which in turn reify and reinforce those ideas, with the gap between these ideal and material existences repeatedly opening and closing. The mock-heroic gestures of Seward and Barbauld and the satires of Moody and Hands give us an insight into how domestic womanhood as a somewhat disingenuous social orthodoxy, and the ground of a disturbing class dynamic, was being recognised and critiqued as such in its own time, and how some women minded some of its gaps. 
Notes

${ }^{1}$ Michael McKeon, The Secret History of Domesticity: Public, Private, and the Division of Knowledge (Baltimore: Johns Hopkins University, 2005) 170.

${ }^{2}$ Nancy Armstrong, Desire and Domestic Fiction: A Political History of the Novel (New York: Oxford University Press, 1989), 8; Eve Tavor Bannet, The Domestic Revolution: Enlightenment Feminisms and the Novel (Baltimore: Johns Hopkins University Press, 2000), 7.

${ }^{3}$ Stuart Curran, 'Romantic Poetry: The I Altered', in Romanticism and Feminism, ed. Anne K. Mellor (Bloomington: Indiana University Press, 1988), 185-207.

${ }^{4}$ Harriet Kramer Linkin, 'Romantic Aesthetics in Mary Tighe and Letitia Landon: How Women Poets Recuperate the Gaze', European Romantic Review 7 (1997): 161.

${ }^{5}$ Adeline Johns-Putra, Heroes and Housewives: Women's Epic Poetry and Domestic Ideology in the Romantic Age (1770-1835) (Bern: Peter Lang, 2001), 23.

${ }^{6}$ For a discussion of women poets using satire to celebrate domesticity, see Adeline Johns-Putra, 'Satirising the Courtly Woman and Defending the Domestic Woman: Mock Epics and Women Poets in the Romantic Age’, Romanticism on the Net 15 (1999), http://www.erudit.org/revue/ron/1999/v/n15/005863ar.html.

${ }^{7}$ Hannah More, Strictures on the Modern System of Female Education; with a View of the Principles and Conduct Prevalent Among Women of Rank and Fortune (London: T. Cadell and W. Davies, 1799), i.5.

${ }^{8}$ See, for example, Moira Ferguson, Eighteenth-Century Women Poets: Nation, Class, and Gender (Albany: State University of New York Press, 1995), 7-25; and Donna Landry The Muses of Resistance: Laboring-Class Women's Poetry in Britain 1739-1796 (Cambridge: Cambridge University Press, 1990), 56-77.

${ }^{9}$ Ann Messenger, Pastoral Tradition and the Female Talent: Studies in Augustan Poetry (New York: AMS Press, 2001) 174. See also Valerie Rumbold, 'The Alienated Insider: Mary Leapor in Crumble Hall’ British Journal for Eighteenth-Century Studies 19 (1996) 63-76; Richard Greene, Mary Leapor: A Study in Eighteenth-Century Women's Poetry (Oxford: Clarendon Press,1993) 137-42 and Donna Landry, Muses of Resistance, 78-119. ${ }^{10}$ Anna Seward, 'Receipt for a Sweet Jar', in The Poetical Works of Anna Seward; with Extracts from Her Literary Correspondence, ed. Walter Scott (Edinburgh, 1810), i.110112, hereafter cited in line numbers.

${ }^{11}$ Anna Seward, 'An Accurate Receipt for a Sweet Jar in Inaccurate Heroics', Lichfield, Lichfield Record Office, Anna Seward Papers, D262/1/35.

12 The version cited here is from Anna Letitia Barbauld, The Poems of Anna Letitia Barbauld, ed. William McCarthy and Elizabeth Kraft (Athens: The University of Georgia Press, 1994), hereafter cited in line numbers.

13 Elizabeth Kraft, ‘Anna Letitia Barbauld's “Washing-Day” and the Montgolfier Balloon’, Literature and History 4.2 (1991): 30.

${ }^{14}$ Kraft, ‘Anna Letitia Barbauld’s “Washing-Day”, 31.

${ }^{15}$ Haley Bordo, 'Reinvoking the "Domestic Muse”: Anna Laetitia Barbauld and the Performance of Genre’, European Romantic Review 11 (2000): 191. 
${ }^{16}$ Messenger, His and Hers: Essays in Restoration and Eighteenth-Century Literature (Lexington: University Press of Kentucky, 1986), 188.

${ }^{17}$ Messenger, His and Hers, 188.

${ }^{18}$ Messenger, His and Hers, 189.

${ }^{19}$ Kraft, 'Anna Letita Barbauld's "Washing-Day”, 31.

${ }^{20}$ Bordo, 'Reinvoking the "Domestic Muse", 33.

${ }^{21}$ Messenger, His and Hers, 193.

${ }^{22}$ Messenger, His and Hers, 193.

${ }^{23}$ Bordo, 'Reinvoking the "Domestic Muse", 193.

${ }^{24}$ Bordo, 'Reinvoking the "Domestic Muse", 193.

${ }^{25}$ Kraft, 'Anna Letita Barbauld's "Washing-Day”, 26.

${ }^{26}$ Kraft, 'Anna Letita Barbauld’s "Washing-Day”, 33.

27 Jan Wellington, 'The Poems and Prose of Elizabeth Moody' (PhD diss., University of New Mexico, 1997) 2-12.

${ }^{28}$ Mary A. Waters, British Women Writers and the Profession of Literary Criticism, 1789-1832 (Basingstoke: Palgrave-Macmillan, 2004), 142.

${ }^{29}$ Waters, British Women Writers, 141-45.

${ }^{30}$ See Wellington, 'The Poems and Prose of Elizabeth Moody' and Roger Lonsdale, ed., Eighteenth-Century Women Poets (Oxford: Oxford University Press, 1989). The versions cited here are from Elizabeth Moody, Poetic Trifles (London: T. Cadell and W. Davies, 1798), hereafter cited in line numbers.

${ }^{31}$ Donna Landry, The Muses of Resistance: Laboring-Class Women's Poetry in Britain 1739-1796 (Cambridge: Cambridge University Press, 1990) 272.

32 Armstrong, Desire and Domestic Fiction, 78.

33 See Elizabeth Hands, The Death of Amnon: A Poem, introd. Caroline Franklin (London: Routledge/Thoemmes Press, 1996) and Lonsdale, Eighteenth-Century Women Poets. The versions cited here are from Elizabeth Hands, The Death of Amnon. A Poem. With an Appendix Containing Pastorals, and other Poetical Pieces (Coventry: N. Rollason, 1789), hereafter cited in line numbers.

${ }^{34}$ Landry, Muses of Resistance, 187.

${ }^{35}$ Landry, Muses of Resistance, 186. 